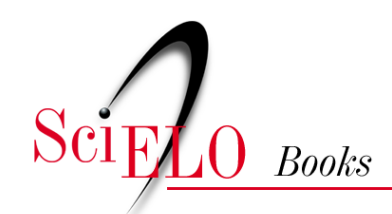

\title{
Movimento dos Pequenos Agricultores (MPA)
}

\author{
José Carlos Radin \\ Gentil Corazza
}

\section{SciELO Books / SciELO Livros / SciELO Libros}

RADIN, J.C., and CORAZZA, G. Movimento dos Pequenos Agricultores (MPA). In: Dicionário histórico-social do Oeste catarinense [online]. Chapecó: Editora UFFS, 2018, pp. 108-109. ISBN: 978-85-64905-65-8. https://doi.org/10.7476/9788564905658.0025.

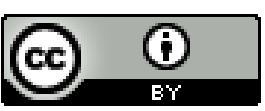

All the contents of this work, except where otherwise noted, is licensed under a Creative Commons Attribution 4.0 International license.

Todo o conteúdo deste trabalho, exceto quando houver ressalva, é publicado sob a licença Creative Commons Atribição 4.0.

Todo el contenido de esta obra, excepto donde se indique lo contrario, está bajo licencia de la licencia $\underline{\text { Creative Commons }}$ Reconocimento 4.0. 


\section{Movimento dos Pequenos Agricultores (MPA)}

O Movimento dos Pequenos Agricultores (MPA) é um movimento social camponês, de caráter popular, de massa, autônomo e de luta permanente, constituído por grupos de pequenos agricultores organizados nacionalmente. Seu principal objetivo é a produção de comida saudável para as próprias famílias e também para todo o povo brasileiro, garantindo, assim, a soberania alimentar do país. Além disso, busca o resgate da identidade e da cultura camponesa, respeitando as diversidades regionais.

O MPA surgiu da crise do movimento sindical e da crise do modelo de agricultura apoiado na revolução verde, que gerou empobrecimento e exclusão no campo. Ele também se inspirou nas lutas de outros movimentos populares, como o das comunidades eclesiais de base, a Comissão Pastoral da Terra e o próprio Movimento dos Trabalhadores Rurais Sem-Terra, que apontaram caminhos para a construção deste novo movimento.

O fim do departamento rural da Central Única dos Trabalhadores (CUT) deixou órfãos e abandonados muitos sindicatos combativos, os quais se viram forçados a buscar outras formas de organização. Algumas lideranças, membros do Departamento Rural da CUT, iniciaram tratativas a respeito da necessidade de criar outro movimento com esse caráter. O primeiro chamamento aconteceu por ocasião da seca, que atingiu o Sul do Brasil no final de 1995 e início de 1996. O Acampamento da Seca, que se imaginava reunir entre 3 mil e cinco mil pessoas, com o objetivo de reivindicar mais crédito para a manutenção familiar, em poucos dias de acampamento já reunia mais de 30.000 . No final de 1997, houve um primeiro encontro nacional visando iniciar um movimento dos pequenos agricultores e, em julho de 1998, um segundo encontro conseguiu definir as principais características do MPA: um movimento de massas, de luta permanente, com organização de base e com bandeiras simples, claras e objetivas. O MPA 
integra a Via Campesina, uma articulação internacional de movimentos camponeses que, junto com outros movimentos e setores da sociedade, luta por um projeto popular de desenvolvimento para o Brasil.

No Oeste catarinense, o MPA está representado pela Associação dos Pequenos Agricultores do Oeste Catarinense (APACO), uma Organização Não Governamental, sem fins lucrativos. Ela foi fundada em 20 de novembro de 1989, com o objetivo de estimular e assessorar o desenvolvimento da agricultura de grupo e mesmo implementar na região um novo modelo de desenvolvimento, baseado na solidariedade e sustentabilidade. Sua criação contou com o apoio decisivo do movimento sindical, popular e de setores da Igreja. Fundamenta-se na agroecologia e na agroindústria familiar associativa de pequeno porte, na busca de melhores condições de vida para os pequenos agricultores familiares da região. É formada e dirigida por grupos de agricultores familiares que se organizam e desenvolvem atividades de forma cooperada. Sua sede está localizada na cidade de Chapecó.

Atualmente o MPA está organizado em 17 estados da Federação. Seu plano camponês de lutas assenta-se em dois pilares: as condições para produzir e as condições para viver bem no campo e se confronta diretamente com o Plano do Agronegócio. Em sua breve história, o MPA já obteve muitas conquistas, tais como a afirmação do conceito de campesinato e da identidade camponesa, a elaboração do Plano Camponês, a conquista do crédito subsidiado para os pequenos agricultores e o crédito para as habitações no campo, entre outras.

\section{REFERENCIAS}

ASSOCIAÇÃO DOS PEQUENOS AGRICULTORES DO OESTE CATARINENSE. Disponível em: <www.apaco.org.br>. Acesso em: 27 abr. 2016.

MOVIMENTO DOS PEQUENOS AGRICULTORES. Disponível em: <www.mpabrasil.org.br>. Acesso em: 27 abr. 2016. 